\title{
Impact assessment of biomass burning on air quality in Southeast and East Asia during BASE-ASIA
}

\author{
Kan Huang ${ }^{\mathrm{a}}$, Joshua S. Fu ${ }^{\mathrm{a}, \mathrm{b}, *}$, N. Christina Hsu ${ }^{\mathrm{c}}$, Yang Gao ${ }^{\mathrm{a}}$, Xinyi Dong ${ }^{\mathrm{a}}$, Si-Chee Tsay ${ }^{\mathrm{c}}$, Yun Fat Lam ${ }^{\mathrm{a}}$ \\ ${ }^{a}$ Department of Civil and Environmental Engineering, The University of Tennessee, Knoxville, TN, USA \\ ${ }^{\mathrm{b}}$ UTK-ORNL Center for Interdisciplinary Research and Graduate Education, Knoxville, TN, USA \\ ${ }^{\mathrm{c}}$ Goddard Space Flight Center, NASA, Greenbelt, MD, USA
}

\section{A R T I C L E I N F O}

\section{Article history:}

Received 5 October 2011

Received in revised form

13 March 2012

Accepted 17 March 2012

\section{Keywords:}

Biomass burning

Southeast Asia

CMAQ

Long-range transport

Aerosol chemical property

Aerosol optical property

\begin{abstract}
A B S T R A C T
A synergy of numerical simulation, ground-based measurement and satellite observation was applied to evaluate the impact of biomass burning originating from Southeast Asia (SE Asia) within the framework of NASA's 2006 Biomass burning Aerosols in Southeast Asia: Smoke Impact Assessment (BASE-ASIA). Biomass burning emissions in the spring of 2006 peaked in March-April when most intense biomass burning occurred in Myanmar, northern Thailand, Laos, and parts of Vietnam and Cambodia. Model performances were reasonably validated by comparing to both satellite and ground-based observations despite overestimation or underestimation occurring in specific regions due to high uncertainties of biomass burning emission. Chemical tracers of particulate $\mathrm{K}^{+}$, OC concentrations, and OC/EC ratios showed distinct regional characteristics, suggesting biomass burning and local emission dominated the aerosol chemistry. CMAQ modeled aerosol chemical components were underestimated at most circumstances and the converted AOD values from CMAQ were biased low at about a factor of 2, probably due to the underestimation of biomass emissions. Scenario simulation indicated that the impact of biomass burning to the downwind regions spread over a large area via the Asian spring monsoon, which included Southern China, South China Sea, and Taiwan Strait. Comparison of AERONET aerosol optical properties with simulation at multi-sites clearly demonstrated the biomass burning impact via longrange transport. In the source region, the contribution from biomass burning to AOD was estimated to be over 56\%. While in the downwind regions, the contribution was still significant within the range of $26 \%-62 \%$
\end{abstract}

(c) 2012 Elsevier Ltd. All rights reserved.

\section{Introduction}

Biomass burning due to forest fires and agricultural waste burning has been a major concern in SE Asia affecting human health, atmospheric visibility, land use, and aquatic ecosystems. Light-absorbing smoke particles warmed upper layers of the atmosphere, reducing surface evaporation and cutting off convection that was an essential part of the hydrological cycle (Ramanathan et al., 2001). Over South Asia, biomass combustion contributed to a two-thirds of the total organic carbon and about $50 \%$ for elemental carbon (Gustafsson et al., 2009). Regional radiative impact of biomass burning aerosols in Asia was estimated ranging from -1.9 to $0.4 \mathrm{Wm}^{-2}$ at top of atmosphere and from -0.5 to $-12.0 \mathrm{Wm}^{-2}$ at surface (Wang et al., 2007). Liu et al. (2003) used

\footnotetext{
* Corresponding author. Department of Civil and Environmental Engineering, The University of Tennessee, 59 Perkins Hall, Knoxville, TN 37996-2010, USA.

E-mail address: jsfu@utk.edu (J.S. Fu).
}

GEOS-Chem to analyze contributions from various sources to the Asian outflow over the West Pacific. Asian biomass burning peaked in March-April and its contribution was comparable to that from Asian anthropogenic emission. Lin et al. (2009) found that convection over Indochina in spring was weak for the vertical transport of pollutants. The existence of the mountain leeside trough could be the most important mechanism for tracers to be transported from surface to above $3 \mathrm{~km}$. Magnitudes of biomass burning emission were highly uncertain and its temporal profiles were especially hard to be determined, causing great difficulties for modeling. A global simulation with GFED biomass burning emission indicated that biomass burning in SE Asia was substantially underestimated due to lack of agricultural fires and the emission bias was more likely from biomass burning than from anthropogenic emissions (Nam et al., 2010).

The urgency of solving smoke haze issues was evident from the initiatives taken by ASEAN (Association of Southeast Asian Nations), such as the agreement on transboundary haze pollution 
(ASEAN, 2002). This study is part of NASA's BASE-ASIA experiment in 2006. SE Asia was a particularly difficult area to perform biomass burning research and it was to a large degree unstudied systematically (Reid et al., 2009). A pilot study on biomass burning in SE Asia had already revealed its great perturbation on $\mathrm{CO}, \mathrm{O}_{3}$, and $\mathrm{PM}_{2.5}$ concentrations (Fu et al., 2011). In this study, we applied a regional atmospheric chemical model CMAQ to understand its feasible application in SE Asia since very limited modeling studies have been documented on the air quality in this region, especially the impact from biomass burning. Seasonal variations and spatial distribution of biomass burning aerosols in SE Asia during the dry season of 2006 were investigated. The effect of long-range transport via the spring Asian monsoon was addressed in this study. For the first time, the contribution of biomass burning to the aerosol optical properties in SE Asia was estimated, which was essential for the climatic effects. Model evaluation with comparison to in-situ ground measurements and satellite observations provided constrains and useful information for the further improvement of biomass burning emission inventory.

\section{Methodology}

\subsection{Model description - WRF and CMAQ}

The Community Multiscale Air Quality Modeling System (CMAQ) model was driven by The Weather Research and Forecasting (WRF) model v3.1.1. In WRF, the final analyses dataset (ds083.2) with a horizontal resolution of $1.0^{\circ} \times 1.0^{\circ}$ and a temporal resolution of six hours from National Centers for Environmental
Prediction (NCEP) was incorporated as initial and boundary conditions. The one-way nested approach with four-dimensional data assimilation (FDDA) in WRF was performed from a mother domain with an $81 \times 81 \mathrm{~km}$ horizontal resolution over Asia nested down to $27 \times 27 \mathrm{~km}$. For CMAQ Lambert conformal projection with true latitude limits of $15^{\circ}$ and $40^{\circ}$ was used on $156 \times 176$ grid cells with horizontal resolution of $27 \mathrm{~km}$. This domain covered SE Asia and part of East Asia, which is shown in Fig. 1. The WRF and CMAQ configurations are listed in Table 1.

\subsection{Emissions and uncertainties}

The biomass burning emission used in this study was from the Fire Locating and Monitoring of Burning Emissions (FLAMBE) (Reid et al., 2009). Fire locations and timing were derived from MODIS active fire detections, and fire fuels were computed based on the Global Land Cover Characterization v2.0 database. FLAMBE had an hourly emission. Biogenic emissions were generated by MEGAN (Model of Emissions of Gases and Aerosols from Nature) v2.02. Hourly meteorological inputs were used to generate the hourly biogenic emissions inventories. Anthropogenic emissions were based on NASA's 2006 Intercontinental Chemical Transport Experiment-Phase B (INTEX-B) emission inventory (Zhang et al., 2009). Fig. S1 shows the spatial distribution of monthly FLAMBE carbon emission from March to May in 2006. And Table S1 summarizes the monthly biomass burning and anthropogenic emissions of $\mathrm{CO}, \mathrm{NOx}, \mathrm{NH}_{3}, \mathrm{SO}_{2}, \mathrm{PM}_{2.5}, \mathrm{OC}$, and $\mathrm{BC}$ in SE Asia at the country level.

In this study, we performed CMAQ simulations with two scenarios. One was referred to as "base case", which included all the

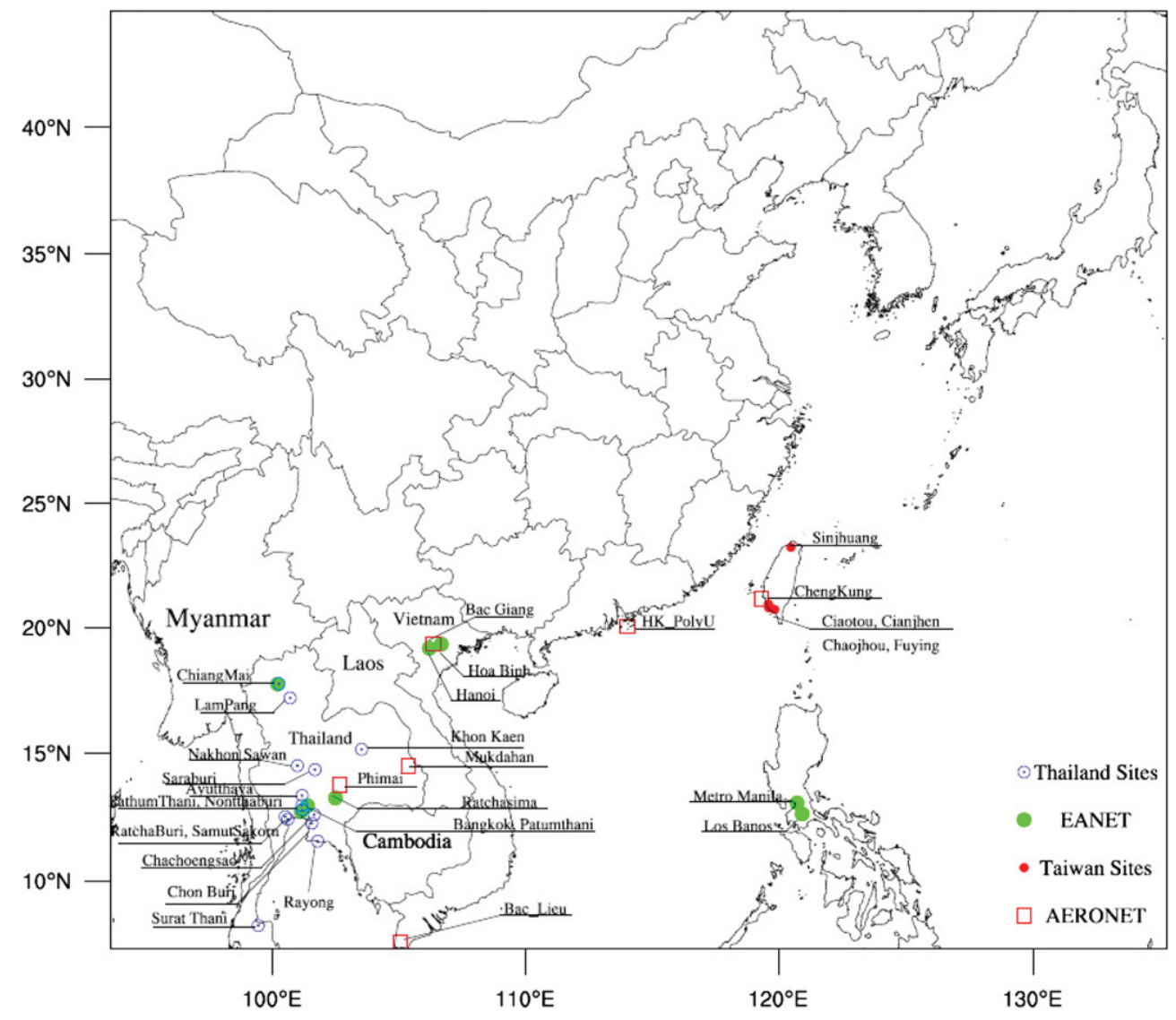

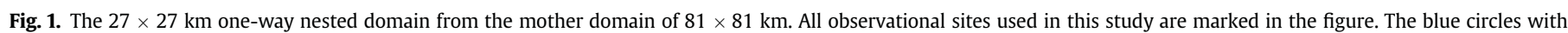
center dot denote monitoring sites in Thailand ( 14 sites); The green filled dots denote sites from EANET (The Acid Deposition Monitoring Network in East Asia) (8 sites); The red dots denote the two supersites in Taiwan; The red squares denote the site from AERONET (The Aerosol Robotic Network) (6 sites). More detailed descriptions of each site are summarized in Table 2. (For interpretation of the references to color in this figure legend, the reader is referred to the web version of this article.) 
Table 1

Model configuration of WRF and CMAQ.

\begin{tabular}{ll}
\hline WRF configuration & WRF v3.1.1 \\
$\begin{array}{l}\text { Meteorology model } \\
\text { Explicit precipitation scheme }\end{array}$ & WRF single - moment 3 - class scheme \\
Longwave Radiation & RRTM \\
Shortwave Radiation & Dudhia scheme \\
Surface-layer option & MM5 similarity (Monin - Obukhov scheme) \\
Land-surface & Thermal diffusion scheme \\
Advection & Global mass-conserving scheme \\
Planetary boundary & YSU \\
$\quad$ layer scheme & \\
Cumulus option & Grell \\
CMAQ configuration & \\
Chemistry model & CMAQ v4.6 \\
Horizontal resolution & $27 \times 27$ km \\
Vertical resolution & 19 sigma-pressure levels \\
& (with the top pressure of 100 mb) \\
Projection & Lambert Conformal Conic \\
Advection & Piecewise parabolic scheme \\
Vertical diffusion & K-theory \\
Gas-phase chemistry & CB05 with Euler Backward Iterative solver \\
Dry deposition & Wesely, 1989 \\
Wet deposition & Henry's law \\
Aqueous chemistry & Walcek and Aleksic, 1998 \\
Aerosol mechanism & AERO4 \\
\hline
\end{tabular}

emission sources, i.e, biomass burning emissions, anthropogenic emissions and natural emissions. The other scenario had the same emission sources with the biomass burning emissions removed. It was referred to as "control case". The differences between the two scenarios thus provided the contribution from biomass burning emission.

\subsection{Ground-based observations}

\subsubsection{Observational sites in SE Asia (Thailand)}

A number of monitoring stations operated by Pollution Control Department (PCD) of Ministry Natural Resources and Environment of Thailand routinely measured air quality parameters on a daily basis. Pollutants measured in these sites include $\mathrm{PM}_{10}, \mathrm{CO}, \mathrm{SO}_{2}$, $\mathrm{NO}_{2}$, and $\mathrm{O}_{3}$. Totally 14 sites were selected and used in this study after checking the completeness of data. The locations of each site are plotted in Fig. 1 (blue circle with center dot) and described in Table 2. According to the site grouping criteria using by PCD (2006), all sites in Thailand were grouped into four regions based on their geographic locations. The north region contained Chiang Mai and Lampang. The northeast region had one site of Khon Kaen. The central region contained Nakhon Sawan, Saraburi, Ayutthaya, and Nonthaburi, with the other sites were grouped into the south region.

\subsubsection{EANET}

The Acid Deposition Monitoring Network in East Asia (EANET) is an international network that involved over 10 countries in Asia, which aimed to monitor wet deposition, dry deposition, soil and vegetation, and inland aquatic environment in Asian countries. Gaseous $\left(\mathrm{SO}_{2}, \mathrm{HNO}_{3}, \mathrm{HCl}, \mathrm{NH}_{3}\right)$ and particulate $\left(\mathrm{SO}_{4}^{2-}, \mathrm{NO}_{3}^{-}, \mathrm{Cl}^{-}\right.$, $\mathrm{Na}^{+}, \mathrm{K}^{+}, \mathrm{NH}_{4}^{+}, \mathrm{Ca}^{2+}, \mathrm{Mg}^{2+}$ ) measurements were made with sampling frequency of weekly or biweekly. The instruments and methods for the chemical analysis were described in the EANET Data Report 2006 (EANET, 2007). The EANET sites used in this study included two sites in Vietnam (Hanoi and Hoa Binh), four sites in Thailand (Bangkok, Patumthani, Chiang Mai, and Nakhon Ratchasima), and two sites in Philippines (Manila and Los Banos). Their locations are plotted in Fig. 1 (green dot) and described in Table 2.
Table 2

Description of the observational datasets, including the data source, site location, site name and parameters measured.

\begin{tabular}{|c|c|c|c|c|c|}
\hline Dataset & $\begin{array}{l}\text { Country/ } \\
\text { Region }\end{array}$ & Site name & Latitude & Longitude & $\begin{array}{l}\text { Parameters } \\
\text { measured }\end{array}$ \\
\hline $\begin{array}{l}\text { Thailand } \\
\text { PCD* }\end{array}$ & Thailand & $\begin{array}{l}\text { Chiang Mai } \\
\text { Lampang } \\
\text { Khon Kaen } \\
\text { NakhonSawan } \\
\text { Saraburi } \\
\text { Ayutthaya } \\
\text { Nonthaburi } \\
\text { Chonburi } \\
\text { Samut Sakorn } \\
\text { Rayong } \\
\text { Chachoengsao } \\
\text { Surat Thani } \\
\text { Ratchaburi } \\
\text { Pathum Thani }\end{array}$ & \begin{tabular}{r|}
18.78 \\
18.27 \\
16.50 \\
15.58 \\
15.50 \\
14.42 \\
13.85 \\
13.35 \\
13.40 \\
12.67 \\
13.70 \\
9.10 \\
13.50 \\
14.01
\end{tabular} & $\begin{array}{r}98.98 \\
99.53 \\
102.78 \\
100.17 \\
100.92 \\
100.50 \\
100.57 \\
101.02 \\
100.02 \\
101.33 \\
101.08 \\
99.33 \\
99.90 \\
100.53\end{array}$ & $\begin{array}{l}\mathrm{PM}_{10}, \mathrm{CO}, \mathrm{O}_{3}, \\
\mathrm{NO}_{2}, \mathrm{SO}_{2}\end{array}$ \\
\hline EANET* & $\begin{array}{l}\text { Vietnam } \\
\text { Thailand }\end{array}$ & $\begin{array}{l}\text { Hanoi } \\
\text { Hoa Binh } \\
\text { Chiang Mai } \\
\text { Bangkok } \\
\text { Pathum } \\
\text { Thani } \\
\text { Ratchasima } \\
\text { Manila } \\
\text { Los Banos }\end{array}$ & $\begin{array}{l}21.02 \\
20.82 \\
18.77 \\
13.77 \\
14.03 \\
\\
\\
14.45 \\
14.63 \\
14.18\end{array}$ & $\begin{array}{r}105.85 \\
105.33 \\
98.93 \\
100.53 \\
100.77 \\
\\
101.88 \\
121.07 \\
121.25\end{array}$ & $\begin{array}{l}\mathrm{SO}_{2}, \mathrm{HNO}_{3}, \mathrm{HCl}, \\
\mathrm{NH}_{3}, \mathrm{NO}-\mathrm{NO}_{2}- \\
\mathrm{NOx}, \mathrm{O}_{3}, \mathrm{PM}_{2.5} \\
\text { chemical } \\
\text { composition: } \\
\left(\mathrm{SO}_{4}^{2-}, \mathrm{NO}_{3}^{-}, \mathrm{Cl}^{-},\right. \\
\mathrm{Na}^{+}, \mathrm{K}^{+}, \mathrm{NH}_{4}^{+}, \\
\left.\mathrm{Ca}^{2+}, \mathrm{Mg}^{2+}\right)\end{array}$ \\
\hline $\begin{array}{l}\text { Taiwan } \\
\text { Supersites }\end{array}$ & $\begin{array}{l}\text { Taiwan } \\
\text { (north) }\end{array}$ & $\begin{array}{l}\text { Ciaotou } \\
\text { Cianjhen } \\
\text { Chaojhou } \\
\text { Fuying } \\
\text { Sinjhuang }\end{array}$ & $\begin{array}{l}22.76 \\
22.61 \\
22.52 \\
22.60 \\
25.03\end{array}$ & $\begin{array}{l}120.30 \\
120.30 \\
120.56 \\
120.39 \\
121.45\end{array}$ & $\begin{array}{l}\mathrm{CO}, \mathrm{O}_{3}, \mathrm{NH}_{3} \text {, } \\
\mathrm{NO} / \mathrm{NOy} \mathrm{PM}_{10} \text {, } \\
\mathrm{PM}_{2.5}, \mathrm{PM}_{2.5} \\
\text { composition: } \\
\left(\mathrm{SO}_{4}^{2-}, \mathrm{NO}_{3}^{-} \text {, }\right. \\
\mathrm{OC}, \mathrm{EC}), \text { particle } \\
\text { scattering/ } \\
\text { absorption } \\
\text { coefficient }\end{array}$ \\
\hline AERONET* & $\begin{array}{l}\text { Thailand } \\
\text { Vietnam } \\
\text { Hongkong } \\
\text { Taiwan }\end{array}$ & $\begin{array}{l}\text { Phimai } \\
\text { Mukdahan } \\
\text { Bac_Giang } \\
\text { Bac_Lieu } \\
\text { HK_PolyU } \\
\text { Cheng Kung }\end{array}$ & $\begin{array}{r}15.00 \\
16.00 \\
21.00 \\
9.00 \\
22.00 \\
23.00\end{array}$ & $\begin{array}{l}102.00 \\
104.00 \\
106.00 \\
105.00 \\
114.00 \\
120.00\end{array}$ & $\begin{array}{l}\text { Aerosol Optical } \\
\text { Depth (AOD), } \\
\text { Aerosol } \\
\text { absorption } \\
\text { Optical Depth, } \\
\text { Single Scattering } \\
\text { Albedo (SSA) }\end{array}$ \\
\hline
\end{tabular}

Thailand PCD* - Pollution Control Department of Ministry Natural Resources and Environment of Thailand.

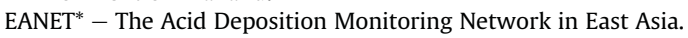

AERONET* - The Aerosol Robotic Network.

\subsubsection{Taiwan supersites}

Two supersites from Taiwan were utilized in this study. The southern supersite is located in the Kaohsiung County and the northern supersite is located in Taipei (Fig. 1, red dot). The southern supersite has one core station with three remote stations. The core station is located at FuyingUniversity and the three remote stations are located at Ciaotou, Cianjhen, and Chaojhou. At all sites, continuous and high-time resolved measurements were made for $\mathrm{PM}_{2.5}$ chemical composition ( $\mathrm{SO}_{4}^{2-}, \mathrm{NO}_{3}^{-}, \mathrm{OC}$, and $\left.\mathrm{EC}\right)$. The instruments, methods, detection limits, and precisions at the southern supersite were described in Lin et al. (2008). And description of the northern supersite (Sinjhuang) could be found elsewhere (Chang et al., 2007).

\subsubsection{AERONET}

The Aerosol Robotic Network (AERONET) is a global network measuring the aerosol optical properties using the ground-based Sun Photometer (Holben et al., 1998). Aerosol size distribution, refractive index, and single scattering albedo were retrieved using sky radiance almucantar and direct sun measurements (Dubovik and King, 2000). The accuracy of AOD measurements is of the order of \pm 0.03 regarding to the level 2.0 (cloud screened) data. In our study domain, six AERONET sites were available during the 
study period, which included two from Thailand (Phimai, Mukdahan), two from Vietnam (Bac Giang, Bac Lieu), one from Hong Kong (HK_PolyU) and one from Taiwan (National Cheng Kung U.). The locations of each site are also shown in Fig. 1 (red square) and described in Table 2 .

\section{Results and discussion}

\subsection{Spatial distribution of CO between CMAQ and AIRS}

Carbon monoxide ( $\mathrm{CO}$ ) was a good tracer for biomass burning as it had a relative long chemical lifetime with a month or more. Intercomparison of monthly modeled spatial distribution of column CO concentrations (molecules $\mathrm{cm}^{-2}$ ) with observed $\mathrm{CO}$ concentrations from the Atmospheric Infrared Sounder (AIRS) are shown in Fig. 2. CMAQ generally captured the spatial patterns of satellite observations in each month. March was the month when high CO concentrations spread over the largest areas during the study period. There were mainly two high CO zones in the domain. One zone mainly included the Central Eastern China, the North China Plain, some parts of northern China and the Sichuan Basin. The other zone was the SE Asia area that we focused on, mainly including Myanmar and major areas of Thailand. It could be seen that in the dense fire regions, model tended to overestimate the CO concentrations. Overestimation of CO emission in FLAMBE over this region was probably the major cause. In April, the spatial distribution of $\mathrm{CO}$ was as similar as in March to some extent, except that the high CO areas shrunk a lot in both model simulation and
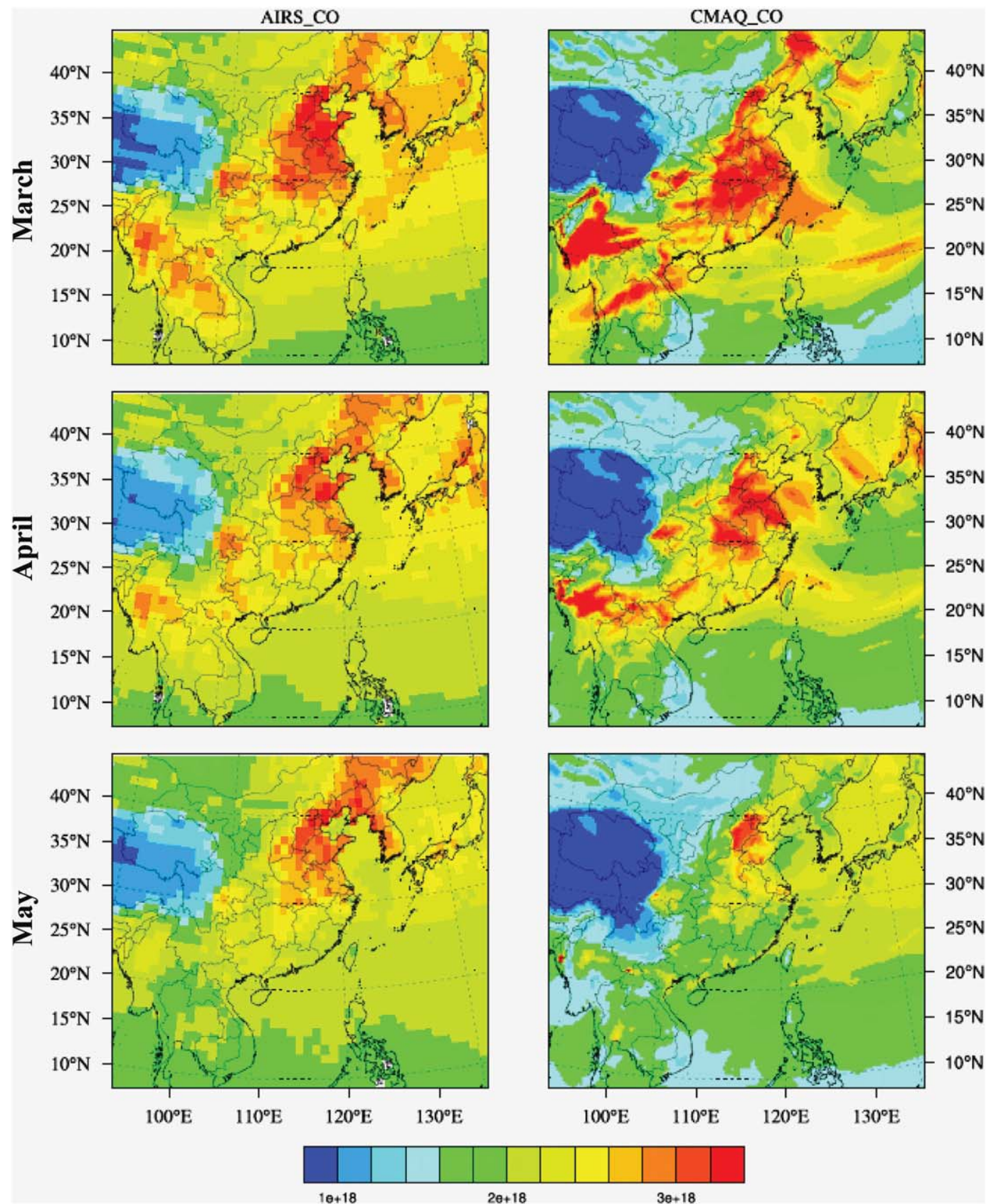

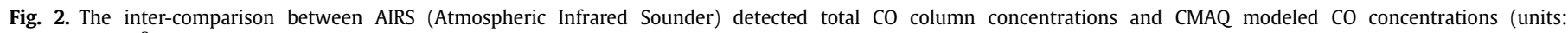
molecules $\mathrm{cm}^{-2}$ ) from March to May, respectively. 
satellite observation. Similarly, the model still overestimated in some dense fire areas. In May, both model and satellite showed much lower CO concentrations in SE Asia, and this was consistent with monthly variations of the carbon emissions shown in Fig. S1. In general, the model could capture the spatial pattern reasonably well.

\subsection{Impact of biomass burning in source regions}

We further evaluated the simulation by using ground observation in Thailand. The modeled CO concentrations of the base case at the surface-layer were compared to measurements by regions as defined in Section 2.3.1. Fig. 3a-d shows the monthly average concentrations of observed $\mathrm{CO}$, modeled total $\mathrm{CO}$, and modeled biomass $\mathrm{CO}$ in four regions of Thailand from March to May, respectively. And Fig. $3 \mathrm{e}-\mathrm{h}$ shows the daily variations of modeled and observed CO. In general, CO peaked in March and April and dropped sharply in May. In northern Thailand, the modeled CO showed the highest concentration, however, it had largest discrepancy with observational result (Fig. 3e). The average observed and modeled CO concentrations in March were 303.2 and $795.0 \mathrm{ppb}$, respectively. In April, they were 151.3 and $351.3 \mathrm{ppb}$, respectively. And in May, they were 125.6 and 105.1 ppbv, respectively. It could be seen that most of the overestimations occurred during March and the first half of April when biomass burning was the most intense. The model performance was relatively good in May when biomass burning emission was negligible. This probably meant that for those days having high fire severity were likely assigned with overestimated emissions. Higher agricultural fires emission factors and/or unexplicit treatment of peatland burning in the FLAMBE emission inventory may be responsible for this (Reid et al., 2009). As shown in Fig. 3a, biomass CO accounted for a major fraction of total CO, and averaged $70-86 \%$ and $61-80 \%$ in March and April, respectively. In the other regions of Thailand, model performances were much better than in northern Thailand. As shown in Fig. $3 \mathrm{f}-\mathrm{h}$, the model had the good capability to capture the temporal variations with similar magnitude. The correlation coefficients between modeled and observed results ranged from $0.5-0.6$ with regression slopes of $0.7-1.6$, indicating the model performance was moderately well. In northeastern Thailand (Fig. 3f), the measured CO average concentration was 291.4, 229.9 and $162.2 \mathrm{ppb}$ from March to May. Similarly, overestimations could be still observed during the peak episodes. On average, biomass $\mathrm{CO}$ contributed about $19-38 \%$ and $23-44 \%$ to the total $\mathrm{CO}$ in this region during March and April. The contribution was much lower than in the northern region, however, it was still

$0 \quad 20040060080010001200$
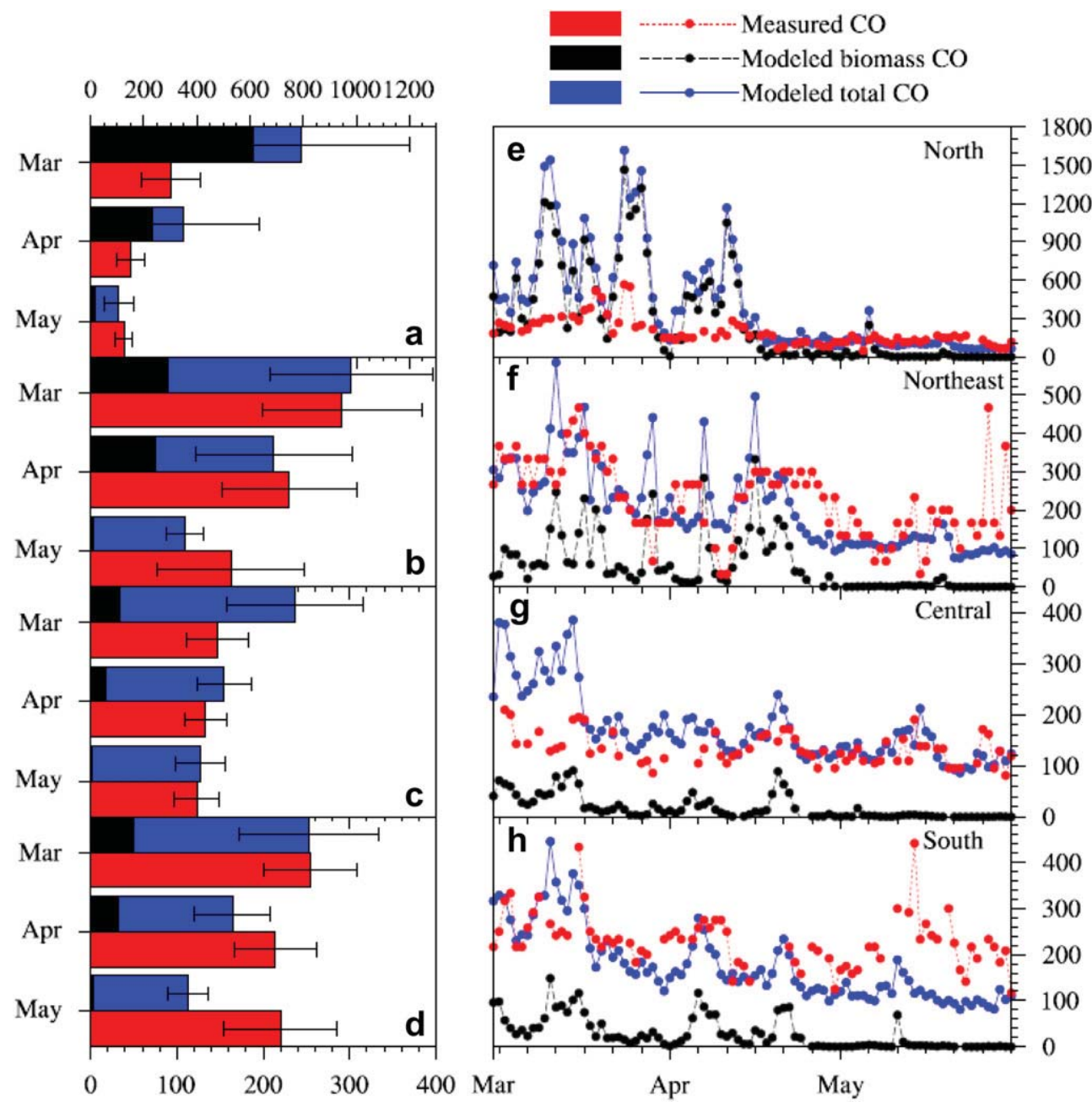

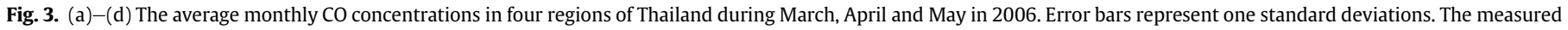

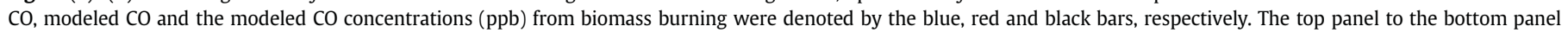

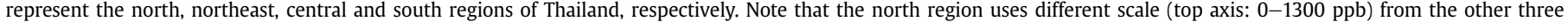

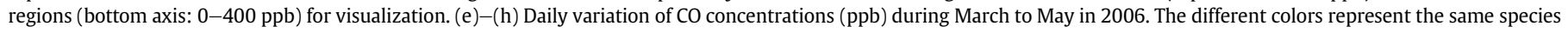
as inferred above. (For interpretation of the references to color in this figure legend, the reader is referred to the web version of this article.) 
significant. The central Thailand had the lowest CO concentration among the four regions, with average monthly concentrations of 147.1, 132.8, and $123.4 \mathrm{ppb}$ during March to May. No distinct temporal variation was observed as indicated from the observational results in Fig. 3g. Overestimation occurred during the first half of March, which could be also due to the overestimated emission. The contribution of biomass burning to $\mathrm{CO}$ was the lowest of less than $15 \%$, indicating central Thailand was only slightly impacted by biomass burning. In southern Thailand, the CO concentrations were higher than the central part while lower than northern and northeastern regions. The contribution of biomass burning was less than $20 \%$ and overestimation was almost not observed in this region. Oppositely, underestimation occurred during the last few days of May. This region covered the provinces of Chachoengsao, Chonburi and Rayong, where Thailand's two main seaports and some power plants and industrial facilities located there (Pham et al., 2007). Thus, the underestimation may be caused by underestimating the local anthropogenic sources. As illustrated from the time-series pattern in the four regions (Fig. $3 \mathrm{e}-\mathrm{h}$ ), we could find that the north and northeast regions exhibited relatively similarly as the two regions both had several consistent $\mathrm{CO}$ peak episodes during March and April. And the central and south regions exhibited similarly which only both had peak episodes during the early March. This meant that north and northeast Thailand were more influenced by biomass burning which could come from the regional transport of adjacent countries such as Myanmar and Laos.

\subsection{Evaluation from ground aerosol chemical measurement}

In this section, the impact of biomass burning on the spatial differences of aerosol chemistry was evaluated by comparison of model simulation to ground-based aerosol chemical measurements. The measurement datasets included the EANET network in SE Asia and the Taiwan supersites in the downwind region. $\mathrm{K}^{+}$was a good indicator for biomass burning (Andreae, 1983), and its monthly concentrations at the eight EANET sites are shown in Fig. 4c. $\mathrm{K}^{+}$showed highest levels at Hanoi in Vietnam, with average concentrations of $2.48,2.17$, and $2.16 \mu \mathrm{g} \mathrm{m}^{-3}$ from March to May, respectively. The high $\mathrm{K}^{+}$levels indicated intense biomass burning events around that region. However, seasonal variations of $\mathrm{K}^{+}$were not obvious. That was, $\mathrm{K}^{+}$in May was almost identical to that in April. And at the other site of Vietnam, Hoa Binh, $\mathrm{K}^{+}$in May even exceeded that in April and close to that in March. We expected that this tracer should be much lower in May due to sharply reduced biomass burning emission. It's explained that the rise of $\mathrm{K}^{+}$in May could be caused by the local anthropogenic activities such as domestic usage of biofuels, which were not easily to be detected by

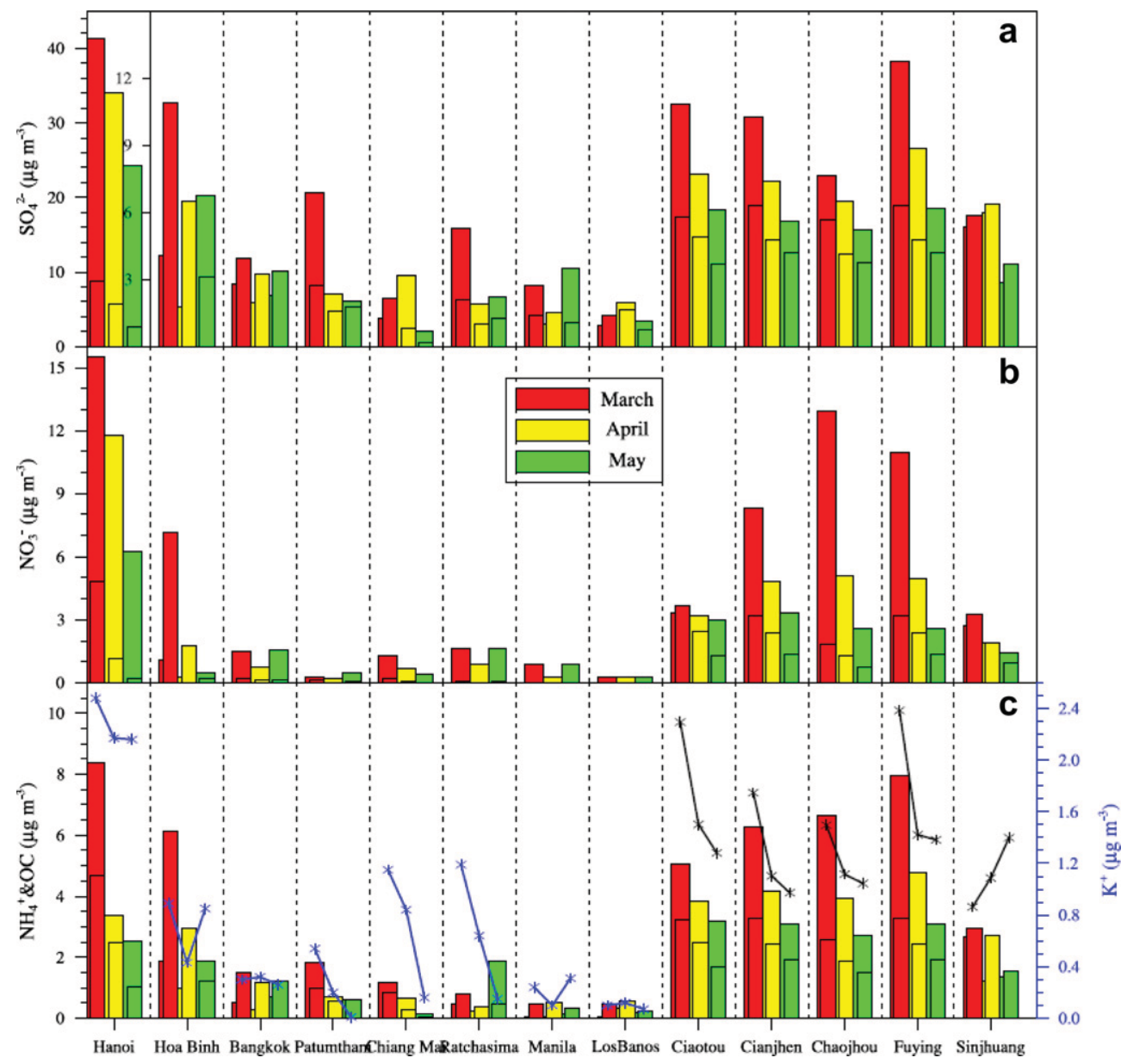

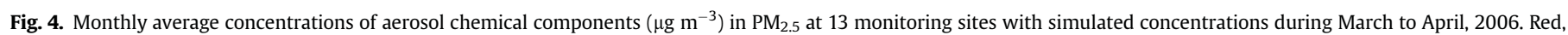

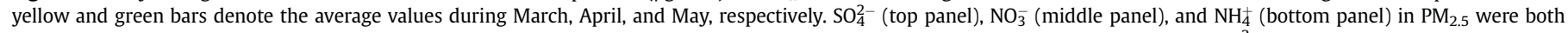

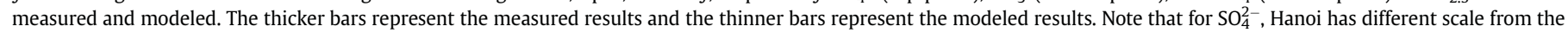

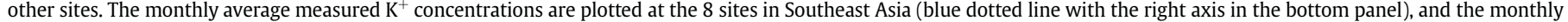

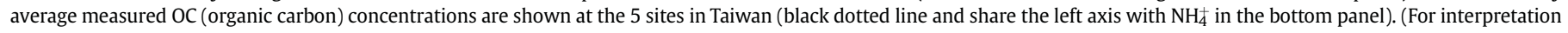
of the references to color in this figure legend, the reader is referred to the web version of this article.) 
remote sensing techniques. Distinct $\mathrm{K}^{+}$levels between Hanoi and Hoa Binh were observed. $\mathrm{K}^{+}$in Hoa Binh was almost a factor of 2-5 lower than in Hanoi, although two sites were closely located (Fig. 1). We assumed the local emission should be more responsible for this as Hanoi is an urban city while Hoa Binh is rural. As for the four sites in Thailand, highest $\mathrm{K}^{+}$levels were observed at Chiang Mai and Nakhon Ratchasima in March with average concentrations of 1.15 and $1.19 \mu \mathrm{g} \mathrm{m}^{-3}$, about $2-3$ times higher than at Bangkok and Patumthani. As shown in Fig. 1, Chiang Mai is located in northern Thailand, and close to Myanmar, where biomass burning was most active. Nakhon Ratchasima is close to Cambodia where also showed strong biomass burning signals (Fig. S1), thus the high $\mathrm{K}^{+}$level at Nakhon Ratchasima was probably attributed to the regional transport from Cambodia and Laos, facilitated by the southeasterly winds (Fig. 6). In April, $\mathrm{K}^{+}$in Chiang Mai and Nakhon Ratchasima decreased to 0.84 and $0.64 \mu \mathrm{g} \mathrm{m}^{-3}$. While in May, it dropped more to 0.16 and $0.15 \mu \mathrm{g} \mathrm{m}^{-3}$. Seasonal variations of $\mathrm{K}^{+}$in Chiang Mai and Nakhon Ratchasima varied consistent with the biomass burning emission in SE Asia, suggesting the dominant role of biomass burning on the aerosol chemistry in these regions. At Patumthani, $\mathrm{K}^{+}$also showed obvious seasonal variations. However, its concentration was much lower compared to Chiang Mai and Nakhon Ratchasima, indicating Patumthani was only moderately impacted by biomass burning. Close to Patumthani, Bangkok also presented relatively low $\mathrm{K}^{+}$level. Both two cities located in the gulf of Thailand along the south sea coast and far away from the intense biomass burning regions. Sea breezes from the ocean facilitated the dispersion of pollutants, which also lowered the aerosol concentrations. As for the two sites in Philippines (Manlia and Los Banos), their concentrations were the lowest among all sites. Although they were also located in SE Asia, the biomass burning emission there usually started to be active from May to October, but not in the spring (Reid et al., 2009).

Taiwan is a good region for the observation of long-range transport of biomass burning as it was often on its transport pathway. Since there was no $\mathrm{K}^{+}$data available in Taiwan, we switched to analyze the $\mathrm{PM}_{2.5}$ organic aerosol as it was a major aerosol component from biomass burning. As shown in Fig. 4c, monthly OC had distinctly decreasing trends at all four sites of the southern supersite in Taiwan. Oppositely, it showed increasing seasonal trends at the northern Taiwan (Sinjhuang). This suggested the southern and northern Taiwan were controlled by different emission sources. In order to explain this difference, we analyzed the correlation between gaseous $\mathrm{CO}$ and $\mathrm{PM}_{2.5} \mathrm{OC}$ with temporal variations of OC/EC ratios at the five sites (Fig. 5). At the four sites in southern Taiwan, $\mathrm{CO}$ and $\mathrm{OC}$ all showed significant correlations with correlation coefficients ranging from 0.72 to 0.90 (Fig. 5a), indicating their common sources. While in northern Taiwan, no such correlation was observed (Fig. 5b). Additionally, the temporal variations of OC/EC also showed regional difference. In southern Taiwan, the OC/EC ratios generally showed decreasing trends although it fluctuated greatly. The elevated OC/EC ratios during March and April suggested the entrainment of other sources such as biomass burning. Biomass burning emissions produced relatively high fraction of OC compared to EC, and thus resulted in enriched OC/EC ratios. In contrast, vehicular and industrial emissions produced relatively lower OC/EC ratios (Andreae and Merlet, 2001). Thus, all evidences indicated southern Taiwan had been impacted by biomass burning. While in northern Taiwan, the temporal OC/EC ratios varied oppositely to southern Taiwan, which
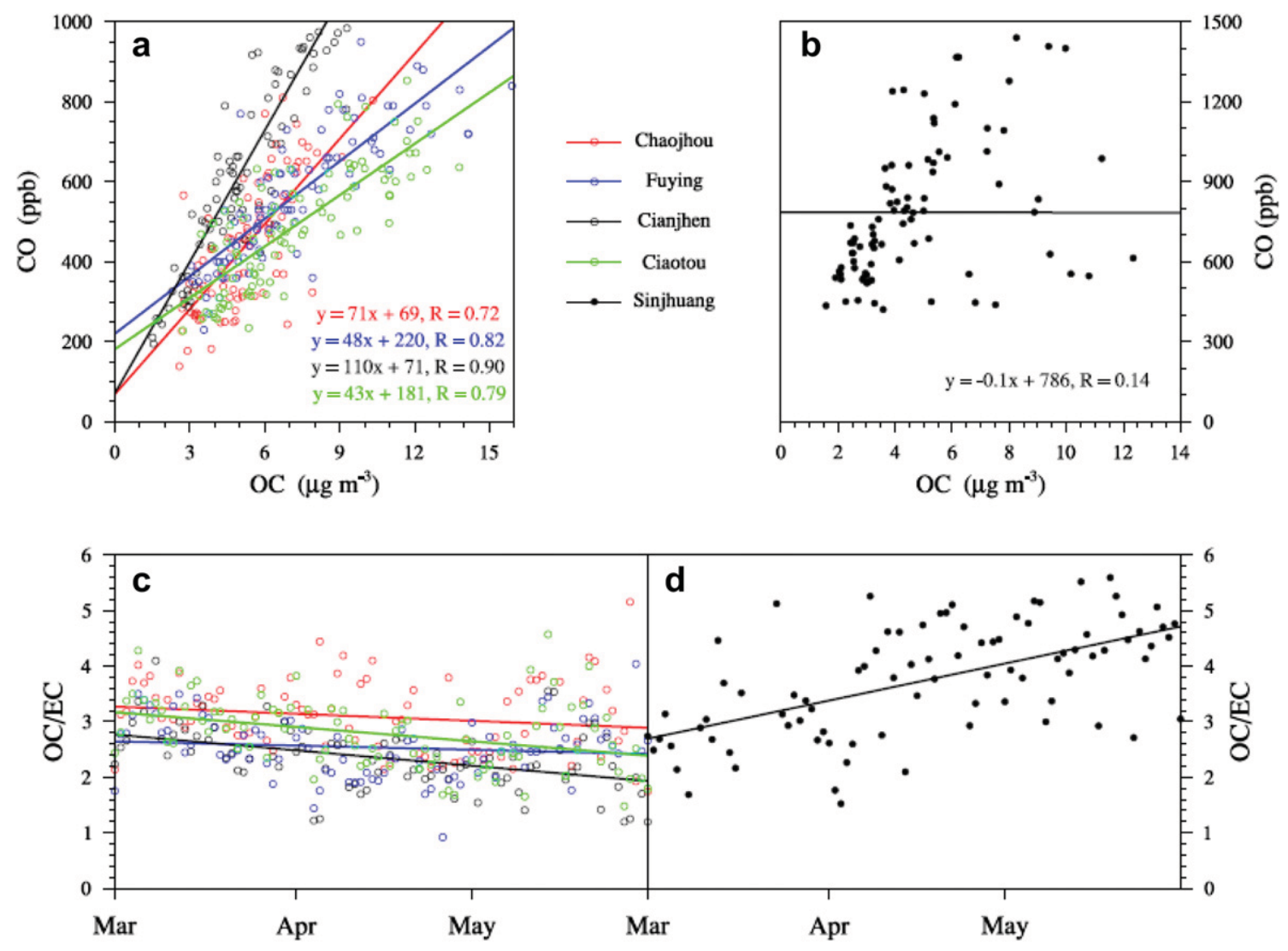

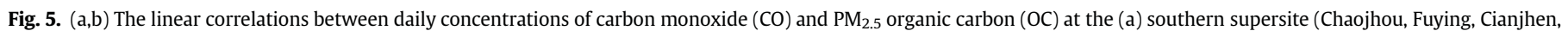

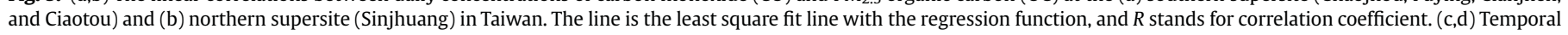
variations of the OC/EC ratios at all sites in Taiwan from March to May in 2006, respectively. 

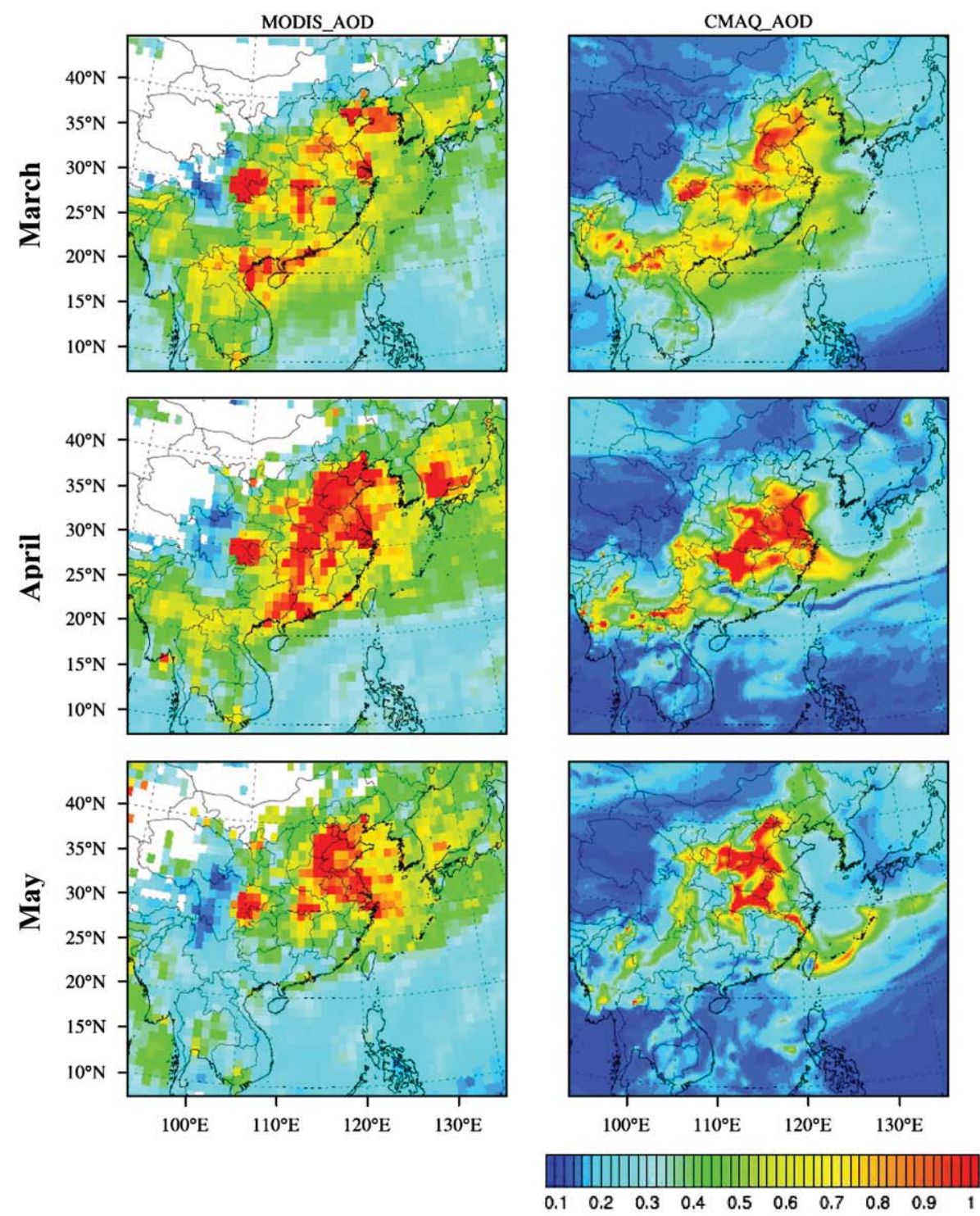
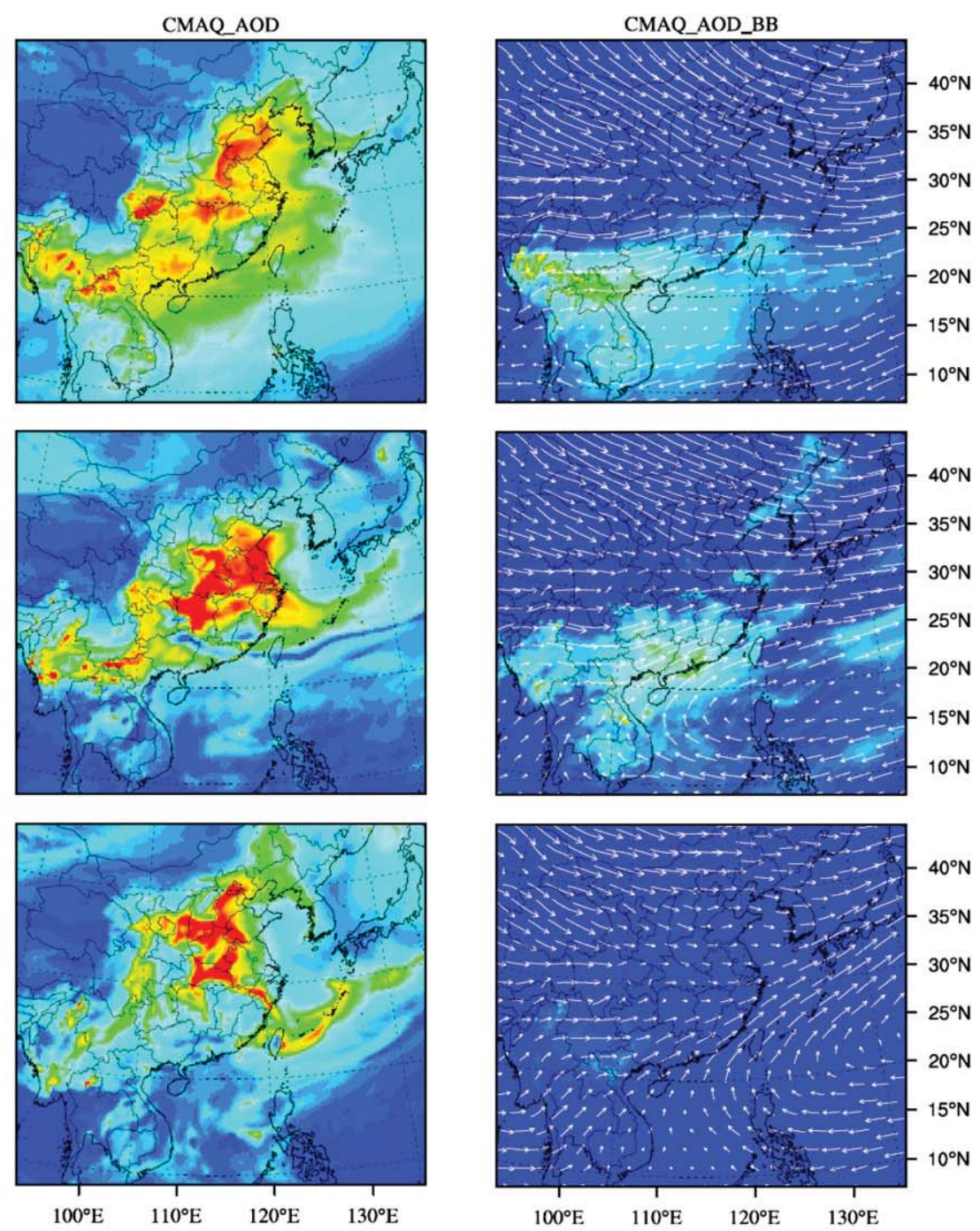

$100^{\circ} \mathrm{E} \quad 110^{\circ} \mathrm{E} \quad 120^{\circ} \mathrm{E} \quad 130^{\circ} \mathrm{E}$

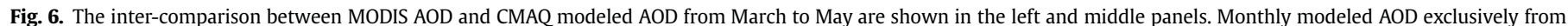
biomass burning is shown in the right panel. The monthly wind fields at altitudes of $2.4 \mathrm{~km}$ (white arrows) are overlaid in the right panel.

presented an increasing trend (Fig. 5d). The OC/EC ratios stayed low at most circumstances in March, which meant biomass burning negligibly impacted there while local emission such as vehicle emission dominated the aerosol chemistry. The OC/EC ratios gradually increased in April and May, indicating the contribution of secondary organic aerosol, which could be derived from the local biogenic emission.

The bars in Fig. 4 show the monthly measured and modeled concentrations of three major secondary inorganic components (i.e, $\mathrm{SO}_{4}^{2-}, \mathrm{NO}_{3}^{-}$, and $\mathrm{NH}_{4}^{+}$) in $\mathrm{PM}_{2.5}$ at all sites. Bigger bars represent measurement and smaller bars represent simulation. Hanoi had much higher pollution than the other cities of SE Asia. The sum of measured $\mathrm{SO}_{4}^{2-}, \mathrm{NO}_{3}^{-}$, and $\mathrm{NH}_{4}^{+}$in $\mathrm{PM}_{2.5}$ reached 65,49 , and $33 \mu \mathrm{g} \mathrm{m}^{-3}$ from March to May, respectively. Peat swamps in SE Asia were enriched in sulfur (Langmann and Graf, 2003), and gaseous $\mathrm{SO}_{2}$ and ammonia could be discharged from the smoldering combustion of peat (See et al., 2006). Also, the neighboring countries could contribute to the high sulfur in Vietnam. As stated by Arndt et al. (1998) and Engardt et al. (2005), only 30-40\% of the sulfur deposition in Vietnam originated from its own domestic sources, with the rest contributed mainly by southern China and Thailand. Thus, long-range transport could be one cause for the high sulfur at Hanoi. However, the simulated sulfate, nitrate and ammonium were biased low by a factor of $5-9,3-10$, and $1.5-2.5$, respectively. The underestimation could be due to various reasons. First, biomass burning emission over this region could be underestimated. Comparison of NAAPS model results to surface observations during an extreme burning event in Indonesia indicated that FLAMBE underestimated the smoke emission by a factor of 3.5 (Hyer and Chew, 2010). Secondly, the local emission could have a great uncertainty. At Hanoi, about $65 \%$ of the $\mathrm{SO}_{2}$ emission came from the domestic cooking, and NOx emission was dominated by motorbikes, these emission sources were highly uncertain (Hung, 2010). Thirdly, we found that if we calculated the neutralization factor of bases on acids, i.e, the equivalent ratio of $\mathrm{NH}_{4}^{+}$versus the sum of $\mathrm{SO}_{4}^{2-}$ and $\mathrm{NO}_{3}^{-}$, the monthly ratio was 0.42 , 0.21 , and 0.23 during March to April, respectively, much lower than 1.0. This meant that a significant fraction of $\mathrm{SO}_{4}^{2-}$ and $\mathrm{NO}_{3}^{-}$didn't exist in the form of $\left(\mathrm{NH}_{4}\right)_{2} \mathrm{SO}_{4}$ and $\mathrm{NH}_{4} \mathrm{NO}_{3}$. We further checked another important alkaline species $\left(\mathrm{Ca}^{2+}\right)$, and found its monthly 
concentration reached $13.63,18.19$, and $16.30 \mu \mathrm{g} \mathrm{m}^{-3}$ from March to May, about 10 times higher than in the wet seasons (EANET, 2007). Forest and peat fires were probably one of the major sources of Carich particles ( $\mathrm{Li}$ et al., 2003). If we incorporated $\mathrm{Ca}^{2+}$ into the bases and re-calculated the neutralization factor, i.e, the equivalent ratio of the sum of $\mathrm{NH}_{4}^{+}$and $\mathrm{Ca}^{2+}$ versus the sum of $\mathrm{SO}_{4}^{2-}$ and $\mathrm{NO}_{3}^{-}$, the ratios were elevated to $1.0-1.5$. Thus, we suspected that the underestimation of modeled sulfate and nitrate should be due to that the heterogeneous reactions of sulfate and nitrate were not well considered in the model. At Hoa Binh, although it is located closely to Hanoi, the measured sulfate, nitrate, and ammonium was about a factor of 5-20 lower. However, the model overestimated about $2-8$ times, and simulated as similar levels as those of Hanoi. This indicated that the emission inventory was not explicit at finer spatial resolution. In Thailand, $\mathrm{SO}_{4}^{2-}, \mathrm{NO}_{3}^{-}$, and $\mathrm{NH}_{4}^{+}$at four sites ranged at levels of $0.69-6.87,0.22-1.6$, and $0.15-1.85 \mu \mathrm{g} \mathrm{m}^{-3}$, respectively. They were much lower than Hanoi, due to the PM emission of Thailand was about $40 \%$ lower than Vietnam (Zhang et al., 2009). The model simulation performed better, probably due to that the emission inventory of Thailand was better than Vietnam. At the downwind sites of Taiwan, the concentration levels were generally higher than in Thailand and Philippines owing to its stronger local anthropogenic sources. At the four sites in southern Taiwan, the modeled inorganic secondary species were biased low in most circumstances. Contrastingly, the model performance was pretty well at the northern supersite (Sinjhuang). Modeled versus measured $\mathrm{SO}_{4}^{2-}, \mathrm{NO}_{3}^{-}$and $\mathrm{NH}_{4}^{+}$generated slopes of $1.15,0.96$, and 1.12 , respectively. Thus, the good model performance here corroborated that the perturbation of biomass burning on the aerosol chemistry in northern Taiwan was negligible. In summary, the spatial variation was moderately reproduced and the discrepancy between model and measurement depended on various factors, such as emission, meteorological parameters, and some immature physical and chemical mechanisms in the model.

\subsection{Aerosol radiative properties}

\subsubsection{Relation between monsoon and impact of biomass burning}

Remote sensing provided useful information on the regional distribution of aerosol optical properties and possible transport pathways. In Fig. 6, the monthly aerosol optical depth (AOD) at the wavelength of $550 \mathrm{~nm}$ with $1^{\circ} \times 1^{\circ}$ resolution was derived from MODIS. The corresponding modeled AOD were inter-compared and the method for converting AOD from CMAQ is described in the Appendix. Generally, the model simulated spatial pattern relatively consistent with MODIS observation in each month. During March in SE Asia, AOD higher than 0.5 spread over Vietnam, the northern Laos, major regions of Myanmar, and northeast Thailand. The high AOD belt extended northeast, which influenced the South China Sea, southern inland China, East China Sea and the Taiwan Strait from the view of both satellite and simulation. The model overestimated AOD over the intense fire regions like Myanmar and Laos while underestimated over major areas of Thailand where less fires occurred. In April, the decreases of AOD over SE Asia were detected by both satellite and model. The long-range transport from source regions to the downwind regions was not as strong as in March. The main high AOD zones were located at the North China Plain, central Eastern China and part of Southern China, which was due to the anthropogenic emission in those industrialized areas and could be partly due to the long-range transport of dust aerosol originating from the Gobi desert in northern China (Huang et al., 2010). In May, AOD over the whole SE Asia dramatically decreased to around 0.3.

Fig. 6 also shows the monthly AOD exclusively from biomass burning with wind fields at altitudes of $2.4 \mathrm{~km}$ (white arrows). In
March, the impact from biomass burning in SE Asia covered a widespread area. In the source regions, AOD could be as high as 0.4 to 0.6 from the impact of biomass burning. Due to prevailing winds from the west and southwest, the impact of biomass burning extended from peninsular SE Asia to the South China Sea, the Taiwan Strait, and some provinces in southern China below $25 \mathrm{~N}^{\circ}$. The most significant impact due to long-range transport was found in Yunnan, Guangxi, Guangdong provinces, the Taiwan Strait and the South China Sea. Less impact was found in regions around $25^{\circ} \mathrm{N}-30^{\circ} \mathrm{N}$ and over the Western Pacific Ocean. In April, impacts from biomass burning in the source regions were still significant and it extended to the latitude of around $30 \mathrm{~N}^{\circ}$, which had covered most of the provinces in southern China. The different spatial distribution patterns of biomass burning AOD between March and April were caused by the wind fields. As shown by the wind vectors in the figure, the average wind fields in March at the latitudes of $17^{\circ} \mathrm{N}-25^{\circ} \mathrm{N}$ dominantly blew from west to east, which pushed the pollutants eastward. Below $17 \mathrm{~N}^{\circ}$, winds blew from the east over the western Pacific and then circulated to higher latitudes which formed an anticyclone, that's why we observed that biomass burning impacted greatly over the South China Sea. In April, the wind fields changed and dominantly blew from low latitudes to the high latitudes which pushed the emitted pollutants more northward and eastward, while the South China Sea was less impacted. In May, the effect of biomass burning on aerosol was almost negligible as illustrated in the figure, owing to the tremendous decreases of biomass burning emissions and advent of wet season.

\subsubsection{Comparison with AERONET}

In order to more explicitly evaluate the spatial and temporal variations of aerosol optical properties in both source and downwind regions, six AERONET sites available during this study period were investigated and compared with simulation results. The measured aerosol optical depth (AOD), absorption aerosol optical depth (AAOD) and single scattering albedo (SSA) at wavelength of $550 \mathrm{~nm}$ were used. SSA was an important and good indicator of the climatic parameter, which was calculated as the ratio of aerosol scattering coefficient to aerosol extinction coefficient (scattering + absorbing). The lower value meant stronger absorbing ability, and vice versa. Fig. 7 shows the time-series of the observed hourly AOD, AAOD and SSA at six AERONET sites. Model results were sampled at the same time and location of each site. The model and observation produced similar temporal variability at all sites, indicating the ability of model to capture day-by-day variabilities. AODs at Phimai and Mukdahan were at similar levels as these two sites didn't locate very far away. Outbreaks of AOD and AAOD mainly occurred in March and some episodes in April, while in May they were almost absent. The monthly mean measured and modeled AOD at Phimai were $0.39 \pm 0.14,0.21 \pm 0.15$ in March, $0.20 \pm 0.11,0.13 \pm 0.09$ in April, and $0.28 \pm 0.26,0.085 \pm 0.065$ in May, respectively. At Mukdahan, the values were $0.48 \pm 0.15$, $0.24 \pm 0.13$ in March, $0.34 \pm 0.16,0.17 \pm 0.14$ in April, and $0.21 \pm 0.15,0.09 \pm 0.06$ in May, respectively. The modeled results were biased low about a factor of 2, like in many parts of the world using FLAMBE (Reid et al., 2009). As for the AAOD, the underestimation was about a factor of 3 . For instance, the measured and modeled value in March was $0.034 \pm 0.018$ and $0.012 \pm 0.015$ at Phimai, and $0.045 \pm 0.018,0.016 \pm 0.012$ at Mukdahan. In the model, AAOD was only related to EC (elemental carbon). Thus, the underestimation could be either due to the underestimation of EC concentrations or the absorption mass efficiency coefficient of EC used in the formula. Consequently, the more underestimated AAOD resulted in higher predicted SSA than measured. The low SSA around 0.90 in March indicated that aerosol was strongly absorbing during this period. Increasing trend of monthly SSA suggested the 

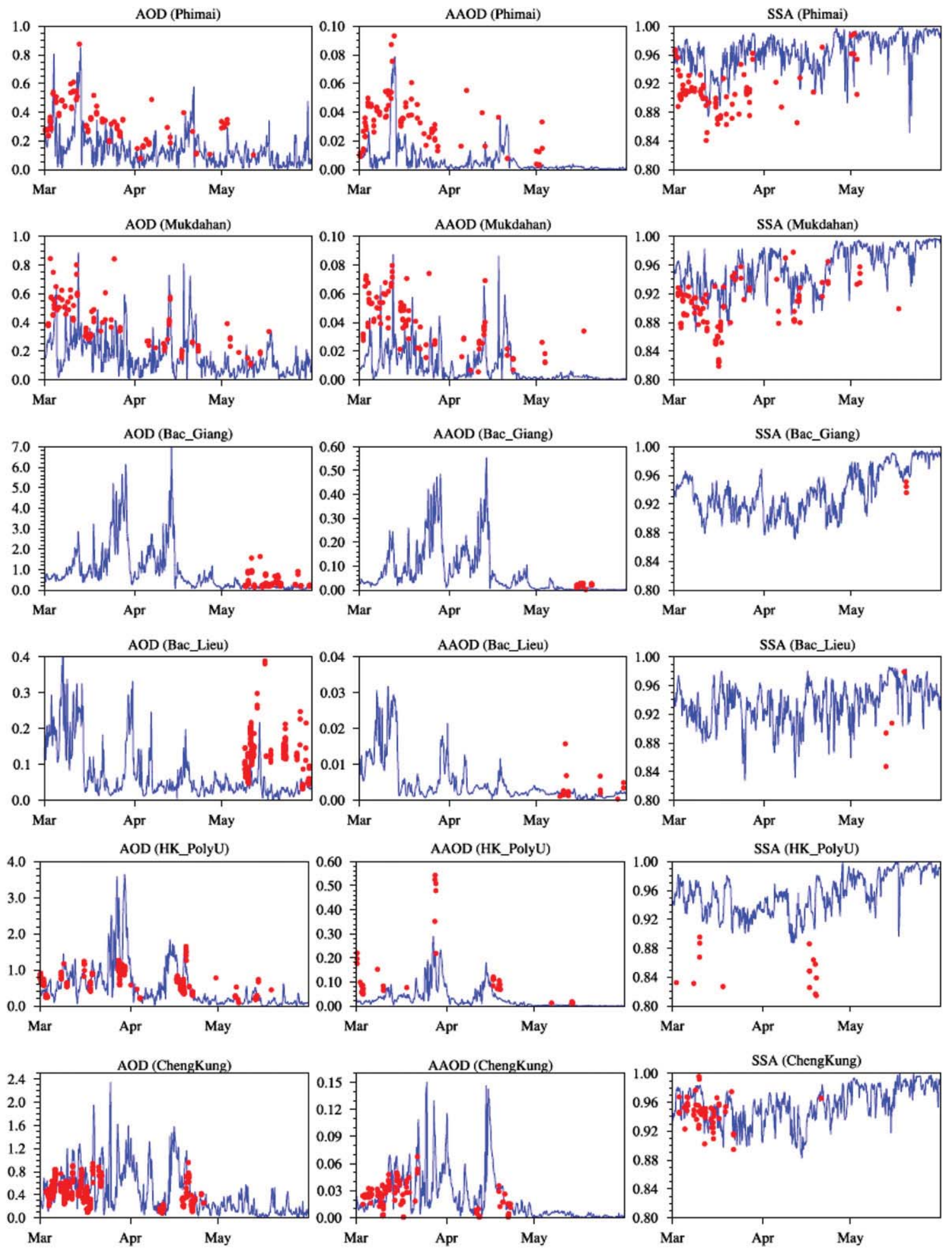

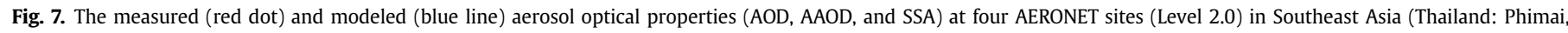
Mukdahan; Vietnam: Bac_Giang, Bac_Lieu) and two downwind sites (HongKong: HK_PolyU; Taiwan: Cheng Kung). Model results are sampled at the same location and time at various sites. SSA measurement data with corresponding AOD values less than 0.4 are removed due to the low confidence (Dubovik et al., 2000; Holben et al., 2006). (For interpretation of the references to color in this figure legend, the reader is referred to the web version of this article.)

decreasing role of elemental carbon on the contribution of aerosol light extinction. And also higher relative humidity during the later periods resulted in fine mode particle growth and an increase in light scattering coefficient (Kotchenruther and Hobbs, 1998). By calculating the difference of modeled AOD between the base case and control case, we could estimate the contribution of biomass burning to the total AOD. In March, biomass emission accounted for an average of $24-35 \%$ and $36-50 \%$ of AOD at Phimai and Mukdahan, respectively. In April, it decreased to $18-29 \%$ and $29-42 \%$, respectively. While In May, the contribution was less than $4 \%$ at 
both sites. Phimai was moderately impacted by biomass burning while Mukdahan was more severely impacted. Among the four sites in SE Asia, Bac Giang evidently showed the strongest aerosol extinction. The modeled monthly AOD from March to May reached $1.52 \pm 1.26,1.10 \pm 1.09$, and $0.15 \pm 0.09$, respectively. It was unfortunate that no measurement data was available during the most intense periods. However, similar high AOD levels as the model results in this study could be observed in the other years, e.g, 2007, 2008 (cf. http://aeronet.gsfc.nasa.gov/). This site is located in the northern part of Vietnam and very close to the EANET Hanoi site (Fig. 1). The highest AOD modeled over this region was consistent with the aerosol chemical analysis in Section 3.3 and satellite image in Section 3.4.1. The contribution from biomass burning to AOD was the highest among all sites with approximately 56-69\% and 59-72\% during March and April, respectively. Times series of AOD and AAOD at Bac Giang showed some concurrent variations with that of Mukdahan, especially during the two highest peaks on March 27-28 and April 13-14. While this temporal consistence was not found at Phimai. Mukdahan is located in the Mekong River region and bordered with Laos, where forest fires dominated. The consistence of temporal variation of aerosol optical properties between Mukdahan and Bac Giang suggested that Mukdahan could be potentially influenced by the intense biomass burning emission from the northern part of SE Asia. While the inconsistence between Phimai and Bac Giang suggested that there was little chance for the biomass burning originating in northern parts of SE Asia to be transported to the central part of Thailand. That's why we found that the contribution of biomass burning was higher at Mukdahan than at Phimai. Except for the peak episodes on March 27-28 and April 13-14, Phimai and Mukdahan had some other concurrent peak episodes during the study period, i.e, March $3 \& 10$, April 17-18, and May 14-15. These high episodes were probably caused by the local biomass burning emission in Thailand, such as land clearing and straw residue burning. Bac Lieu is another site in Vietnam while showed lowest AOD and AAOD values among the four sites in SE Asia. The average monthly modeled AOD values were $0.13 \pm 0.095,0.050 \pm 0.036$, and $0.037 \pm 0.026$, respectively. Bac Lieu is located at the very southern edge of Vietnam and close to the ocean. The low values there should be due to the local weak biomass burning emission (Fig. S1).

In this study, two AERONET sites available at the downwind regions from SE Asia were investigated, including one site in Hong Kong (HK_polyU), and one site in Taiwan (National Cheng Kung U.). At HK_PolyU, AOD and AAOD stayed within certain levels during the first 25 days in March, then suddenly increased near the end of March, which was 3-4 times that the average level of the previous days, indicating the transport from elsewhere. This peak episode corresponded well with that in Bac Giang and three days backward trajectory (Draxler and Rolph, 2003) traced back of the origin of air masses from Myanmar, Laos, Vietnam and southern China (not shown). On March 27, AAOD even reached over 0.5, indicating the accumulation of strong absorbing substances. Another pollution episode occurred on April 13-14, which was also related to the biomass burning from SE Asia as indicated from the consistent peaks in Bac Biang and Mukdahan. The monthly contribution from biomass burning to AOD at HK_PolyU reached 36-50\% and 47-62\% in March and April, respectively, which was even higher than Thailand and only inferior to Bac Giang. This indicated that the long-range transport of biomass burning had tremendous impact on the air quality of Hong Kong. More far away from the source region, the modeled optical properties in Taiwan (TW_ChengKung) also presented evident seasonal change and strong temporal variation. The modeled monthly AOD at TW_ChengKung was $0.67 \pm 0.37$ in March, $0.49 \pm 0.38$ in April, and $0.16 \pm 0.13$ in May, respectively. High AOD and AAOD peaks occurred mainly in the second half of March and near the middle of April, which corresponded to the outbreaks in source region, e.g, Bac Giang, Mukdahan, indicating the large-scale influence via long-range transport. The contribution of biomass burning to AOD at southern Taiwan was about $26-39 \%$ and $27-41 \%$ in March and April, respectively.

\section{Conclusions}

In this paper, we simulated biomass burning in SE Asia during March to May, 2006, by using the Models-3/Community Multiscale Air Quality (CMAQ) model and the FLAMBE biomass burning emission inventory. Ground-based measurement and satellite observation was used to evaluate the model performance. The major findings were presented as below:

(1) Biomass burning emissions in the spring of 2006 peaked in March-April when most intense biomass burning occurred in Myanmar, northern Thailand, Laos, and parts of Vietnam and Cambodia. CMAQ could reasonably well simulate the spatial pattern and temporal variations of $\mathrm{CO}$ in comparison to both satellite and ground measurement. Overestimation or underestimation occurred in different regions due to great uncertainties of the biomass burning emission inventory. The largest discrepancy between modeled and observed $\mathrm{CO}$ occurred in northern Thailand, which overestimated the peak episodes by a factor of 2-3. In the other regions of Thailand where less fires occurred, the simulation performed much better.

(2) Scenario simulation not only modeled significant impact of biomass burning on AOD (0.4-0.6) in SE Asia source regions, but also in the downwind regions. The Asian spring monsoon facilitated the impact of biomass burning extending from peninsular SE Asia to the South China Sea, the Taiwan Strait, and some provinces in southern China. Different spatial distribution patterns of biomass burning AOD between March and April were caused by the different wind fields.

(3) Evaluation of several datasets, i.e, EANET, AERONET, and Taiwan supersites' data, illustrated distinct regional differences of aerosol chemical and optical properties. Local biomass burning, anthropogenic sources and long-range/regional transport were the main factors controlling the aerosol chemistry. Highest concentrations of particulate $\mathrm{K}^{+}, \mathrm{SO}_{4}^{2-}, \mathrm{NO}_{3}^{-}$, and $\mathrm{NH}_{4}^{+}$were observed at Hanoi in Vietnam. Correspondingly, highest AOD and AAOD were modeled at Bac Giang, also in Vietnam. The contribution of biomass burning to AOD was estimated to be over $56 \%$, indicating the significant influence of biomass burning over this region. In Thailand, the magnitudes of major aerosol chemical components, AOD, and AAOD were much lower than in Vietnam. The contribution of biomass burning to AOD was about $18-50 \%$, indicating that Thailand was moderately impacted. In the downwind regions, the contribution of biomass burning to AOD at Hong Kong and Taiwan was significant within the range of $26 \%-62 \%$. The observed monthly mean SSA was around 0.90 during intense biomass burning periods, suggesting the great production of strongly absorbing substances (i.e, EC) due to biomass burning. Modeled concentrations of aerosol chemical components were biased low at most circumstances, and the modeled AOD values were biased low about a factor of 2 , probably due to the underestimation of biomass burning emission.

\section{Acknowledgments}

We thank Thailand PCD, EANET, Taiwan EPA and AERONET for proving the measurement data. We thank Dr. Edward J. Hyer for 
providing FLAMBE biomass burning emission data. We thank NASA GSFC on funding support (grant no.: NNX09AG75G). Data products from SMART-COMMIT and Deep Blue groups of NASA GSFC are funded by the NASA Radiation Sciences Program, managed by Dr. Hal Maring. Hong Kong data was obtained from Hong Kong Environmental Protection Department.

\section{Appendix. Supplementary material}

Supplementary data associated with this article can be found, in the online version, at doi:10.1016/j.atmosenv.2012.03.048.

\section{References}

Andreae, M.O., 1983. Soot carbon and excess fine potassium - long-range transport of combustion-derived aerosols. Science 220, 1148-1151. doi:10.1126 science.220.4602.1148.

Andreae, M.O., Merlet, P., 2001. Emission of trace gases and aerosols from biomass burning. Global Biogeochemical Cycles 15 (4), 955-966. doi:10.1029/ 2000GB001382.

Arndt, R.L., Carmichael, G.R., Roorda, J.M., 1998. Seasonal source-receptor relationships in Asia. Atmospheric Environment 32, 1397-1406.

ASEAN, 2002. ASEAN Agreement on Transboundary Haze Pollution.

Chang, S.Y., Lee, C.T., Chou, C.C.K., Liu, S.C., Wen, T.X., 2007. The continuous field measurements of soluble aerosol compositions at the Taipei aerosol supersite, Taiwan. Atmospheric Environment 41, 1936-1949.

Draxler, R., Rolph, G., 2003. HYSPLIT (HYbrid Single-Particle Lagrangian Integrated trajectory) model. http://www.arl.noaa.gov/ready/hysplit4.html.

Dubovik, O., King, M.D., 2000. A flexible inversion algorithm for retrieval of aerosol optical properties from sun and sky radiance measurements. Journal of Geophysical Research 105 (D16), 20673-20696.

Dubovik, O., Smirnov, A., Holben, B.N., King, M.D., Kaufman, Y.J., Eck, T.F., Slutsker, I. 2000. Accuracy assessments of aerosol optical properties retrieved from AERONET sun and sky-radiance measurements. Journal of Geophysical Research 105 (D8), 9791-9806. doi:10.1029/2000JD900040.

EANET, 2007. EANET Data Report 2006, Acid Deposition Monitoring Network in East Asia (EANET)

Engardt, M., Siniarovina, U., Khairul, N.I., Leong, C.P., 2005. Country to country transport of anthropogenic sulphur in Southeast Asia. Atmospheric Environment 39, 5137-5148.

Fu, J.S., Hsu, N.C., Gao, Y., Huang, K., Li, C., Lin, N.H., Tsay, S.C., 2011. Evaluating the influences of biomass burning during 2006 BASE-ASIA: a regional chemica transport modeling. Atmospheric Chemistry \& Physics Discussion 11, 32205-32243. doi:10.5194/acpd-11-32205-2011.

Gustafsson, O., Krusa, M., Zencak, Z., Sheesley, R.J., Granat, L., Engstrom, E. Praveen, P.S., Rao, P.S.P., Leck, C., Rodhe, H., 2009. Brown clouds over south Asia: biomass or fossil fuel combustion? Science 323, 495-498. doi:10.1126/ science.1164857.

Holben, B.N., Eck, TF, Slutsker, I. Tanre, D, Buis, J.P Setzer, A Vermote, E Reagan, J.A., Kaufman, Y.J., Nakajima, T., Lavenu, F., Jankowiak, I., Smirnov, A. 1998. AERONET - a federated instrument network and data archive for aerosol characterization. Remote Sensing of Environment 66, 1-16.

Holben, B.N., Eck, T.F., Slutsker, I., Smirnov, A., Sinyukc, A., Schaferc, J., Gilesc, D. Dubovik, O., 2006. AERONET's version 2.0 quality assurance criteria. Proceedings of SPIE 6408, 64080Q. doi:10.1117/12.706524.

Huang, K., Zhuang, G.S., Lin, Y.F., Li, J.A., Sun, Y.L., Zhang, W.J., Fu, J.S., 2010. Relation between optical and chemical properties of dust aerosol over Beijing, China. Journal of Geophysical Research 115, D00K16. doi:10.1029/2009JD013212.
Hung, N.T., 2010. Urban air quality modelling and management in Hanoi, Vietnam. PhD Thesis, Aarhus University, National Environmental Research Institute, Denmark, 211 pp.

Hyer, E.J., Chew, B.N., 2010. Aerosol transport model evaluation of an extreme smoke episode in Southeast Asia. Atmospheric Environment 44, 1422-1427.

Kotchenruther, R.A. Hobbs, PV., 1998. Humidification factors of aerosols from biomass burning in Brazil. Journal of Geophysical Research 103 (D24), 32081-32089. doi:10.1029/98JD00340.

Langmann, B., Graf, H., 2003. Indonesian smoke aerosols from peat fires and the contribution from volcanic sulfur emissions. Geophysical Research Letters 30 (11), 1547. doi:10.1029/2002GL016646.

Li, J., Posfai, M., Hobbs, P.V., Buseck, P.R., 2003. Individual aerosol particles from biomass burning in southern Africa: 2, compositions and aging of inorganic particles. Journal of Geophysical Research 108 (D13), 8484. doi:10.1029/ 2002JD002310.

Lin, C.H., Wu, Y.L., Lai, C.H., Watson, J.G., Chow, J.C., 2008. Air quality measurements from the southern particulate matter supersite in Taiwan. Aerosol and Air Quality Research 8 (3), 233-264.

Lin, C.Y., Hsu, H.M., Lee, Y.H., Kuo, C.H., Sheng, Y.F., Chu, D.A., 2009. A new transport mechanism of biomass burning from Indochina as identified by modeling studies. Atmospheric Chemistry \& Physics 9, 7901-7911. doi:10.5194/acp-9-7901-2009.

Liu, H.Y., Jacob, D.J., Bey, I., Yantosca, R.M., Duncan, B.N., Sachse, G.W., 2003. Transport pathways for Asian pollution outflow over the Pacific: interannual and seasonal variations. Journal of Geophysical Research 108 (D20), 8786. doi:10.1029/2002JD003102.

Nam, J., Wang, Y., Luo, C., Chu, D.A., 2010. Trans-Pacific transport of Asian dust and CO: accumulation of biomass burning $\mathrm{CO}$ in the subtropics and dipole structure of transport. Atmospheric Chemistry \& Physics 10, 3297-3308. doi:10.5194/ acp-10-3297-2010.

PCD, 2006. Pollution Control Department, Thailand State of Pollution Report 2006. PCD. 06-026, ISBN 978-974-286-344-9.

Pham, T.B.T., Manomaiphiboon, K., Vongmahadlek, C., 2007. Updated emission estimates of ozone precursors from energy consumption by power plants and industrial facilities in the central and eastern regions of Thailand. Asian Journal on Energy and Environment 08 (01), 483-489.

Ramanathan, V., Crutzen, P.J., Kiehl, J.T., Rosenfeld, D., 2001. Atmosphere - aerosols, climate, and the hydrological cycle. Science 294, 2119-2124. doi:10.1126/ science.1064034.

Reid, J.S., Hyer, E.J., Prins, E.M., Westphal, D.L., Zhang, J.L., Wang, J. Christopher, S.A., Curtis, C.A., Schmidt, C.C., Eleuterio, D.P., Richardson, K.A., Hoffman, J.P., 2009. Global monitoring and forecasting of biomass-burning smoke: description of and lessons from the fire locating and modeling of burning emissions (FLAMBE) Program. IEEE Journal of Selected Topics in Applied Earth Observations and Remote Sensing 2 (3), 144-162. doi:10.1109/ JSTARS.2009.2027443.

See, S.W., Balasubramanian, R., Wang, W., 2006. A study of the physical, chemical, and optical properties of ambient aerosol particles in Southeast Asia during hazy and nonhazy days. Journal of Geophysical Research 111, D10S08. doi:10.1029/2005JD006180.

Wang, S.H., Lin, N.H., Chou, M.D., Woo, J.H., 2007. Estimate of radiative forcing of Asian biomass-burning aerosols during the period of TRACE-P. Journal of Geophysical Research 112, D10222. doi:10.1029/2006JD007564.

Wesely, M.L., 1989. Parameterization of Surface Resistances to Gaseous Dry Deposition in Regional-Scale Numerical Models. Atmospheric Environment 23, 1293-1304.

Walcek, C.J., Aleksic, N.M., 1998. A Simple but Accurate Mass Conservative PeakPreserving, Mixing Ratio Bounded Advection Algorithm with Fortran Code. Atmospheric Environment 32, 3863-3880.

Zhang, Q., Streets, D.G., Carmichael, G.R., He, K.B., Huo, H., Kannari, A., Klimont, Z., Park, I.S., Reddy, S., Fu, J.S., Chen, D., Duan, L., Lei, Y., Wang, L.T., Yao, Z.L., 2009. Asian emissions in 2006 for the NASA INTEX-B mission. Atmospheric Chemistry \& Physics 9, 5131-5153. doi:10.5194/acp-9-5131-2009. 